\title{
New Data on Biota of Some Lakes in the Western Part of the Putorana Plateau
}

\author{
Vladimir A. Zadelenov ${ }^{\mathrm{a}, \mathrm{b}}$, \\ Olga P. Dubovskaya ${ }^{* c, d}$, Lilya V. Bazhina ${ }^{a}$, \\ Larisa A. Glushchenko ${ }^{\mathrm{a}, \mathrm{b}, \mathrm{d}}$, Inara G. Isaeva ${ }^{\mathrm{a}}$, \\ Valentina O. Kleush ${ }^{a}$, Kseniya A. Semenchenko, \\ Viktor V. Matasov and Evgeniy N. Shadrin ${ }^{\mathrm{a}}$ \\ ${ }^{a}$ Scientific Research Institute of Ecology of Fishery Reservoirs \\ 33 Parizhskoy Kommunii Str., Krasnoyarsk, 660097, Russia \\ ${ }^{b}$ Nature Reserves of Taimyr \\ 22 Talnakhskaya Str., Norilsk, 663305, Russia \\ 'Institute of Biophysics SB RAS \\ FRC "Krasnoyarsk Science Center SB RAS" \\ 50/50 Akademgorodok, Krasnoyarsk, 660036, Russia \\ ${ }^{d}$ Siberian Federal University \\ 79 Svobodny, Krasnoyarsk, 660041, Russia \\ ${ }^{e}$ Institute of Biology and Soil Science of FEB RAS \\ 159 Stoletiya Vladivostoka Ave., Vladivostok, 690022, Russia
} Received 03.01.2017, received in revised form 19.02.2017, accepted 04.03.2017

Species composition and abundance of zooplankton and zoobenthos of large Norilsk Lakes (Lama, Sobach'e) and Kutaramakan Lake in the western part of the Putorana plateau were studied in AugustSeptember of 2013-2014 after a long gap. Senecella calanoides Juday (Copepoda: Calanoida) in zooplankton and 5 species of water mites (Acalyptonotus violaceus Walter, Hygrobates (Hygrobates) foreli (Lebert), Lebertia (Mixolebertia) densa Koenike, Lebertia (Pilolebertia) porosa Thor, Oxus (Gnaphiscus) setosus (Koenike) (Hydrachnidia)) in zoobenthos were recorded for the first time in the investigated lakes. A total of 64 taxa of benthic invertebrates were found, of which 42 taxa were Chironomidae. Zooplankton species composition of Lama and Cobach'e lakes was similar and differed from that of Kutaramakan lake by presence of Senecella calanoides and Limnocalanus macrurus Sars (Copepoda: Calanoida). In zoobenthos of Kutaramakan lake amphipods were not found. Lama and Kutaramakan lakes can be classified as ultraoligotrophic water bodies based on biomass of zooplankton and zoobenthos. Among the studied lakes, Cobach'e lake has the greatest biomass, and based on the biomass of zooplankton in some zones of $>0.5 \mathrm{~g} / \mathrm{m}^{3}$, it is an oligotrophic water body, and based on an average biomass of zoobenthos $3.85 \mathrm{~g} / \mathrm{m}^{2}$ an $\alpha$-mesotrophic one.

(C) Siberian Federal University. All rights reserved

* Corresponding author E-mail address: dubovskaya@ibp.krasn.ru 
Keywords: zooplankton, zoobenthos, lake, Lama, Sobach'e, Kutaramakan.

Citation: Zadelenov V.A., Dubovskaya O.P., Bazhina L.V., Glushchenko L.A., Isaeva I.G., Kleush V.O., Semenchenko K.A., Matasov V.V., Shadrin E.N. New data on biota of some lakes in the western part of the Putorana Plateau. J. Sib. Fed. Univ. Biol., 2017, 10(1), 87-105. DOI: 10.17516/1997-1389-0010.

\title{
Новые сведения о биоте некоторых озер западной части плато Путорана
}

\author{
В.А. Заделёнов ${ }^{\mathrm{a}, \tilde{\sigma}}$, О.П. Дубовская ${ }^{\text {,г, }, ~ Л . В . ~ Б а ж и н а ~}$ \\ Л.А. Глущенко ${ }^{\text {a,б,г, И.Г. Исаева }}{ }^{\text {, }, ~ В . О . ~ К л е у ш ~}{ }^{\text {, }}$ \\ К.А. Семенченко \\ ${ }^{a}$ Научно-исследовательский институт \\ экологии рыбохозяйственных водоемов \\ Россия, 660097, Красноярск, ул. Парижской коммуны, 33 \\ ${ }^{6}$ Объединенная дирекиия заповедников Таймыра \\ Россия, 663305, Норильск, ул. Талнахская, 22 \\ ${ }^{6}$ Институт биофизики СО РАН \\ ФИЦ «Красноярский научный центр СО РАН» \\ Россия, 660036, Красноярск, Академгородок, 50/50 \\ 'Сибирский федеральныий университет \\ Россия, 660041, Красноярск, пр. Свободный, 79 \\ 'Биолого-почвенный институт ДВО РАН \\ Россия, 690022, Владивосток, пр. 100-летия Владивостока, 159
}

В августе-сентябре 2013-2014 г2. проведены исследования зоопланктона и зообентоса Больших Норильских озер (Лама, Собачье) и оз. Кутарамакан в западной части плато Путорана для изучения их видового состава и количественных показателей после длительного перерыва. В зоопланктоне веслоногий рачок Senecella calanoides Juday (Copepoda: Calanoida), а в зообентосе 5 видов водяных клещей Acalyptonotus violaceus Walter, Hygrobates (Hygrobates) foreli (Lebert), Lebertia (Mixolebertia) densa Koenike, Lebertia (Pilolebertia) porosa Thor, Oxus (Gnaphiscus) setosus (Koеnike) (Hydrachnidia) впервые указаны для исследованных озер. Всего в бентосе найдено 64 таксона беспозвоночных, из них 42 таксона Chironomidae. Состав зоопланктона озер Лама и Собачье сходен и отличается от такового оз. Кутарамакан наличием калянид Limnocalanus macrurus u Senecella calanoides, отсутствуюших в последнем. В зообентосе оз. Кутарамакан не обнаружены бокоплавы. По биомассе зоопланктона и зообентоса озера Лама и Кутарамакан могут быть отнесены к ультраолиготрофным. Из исследованных озер Собачье отличается наибольшей биомассой и по биомассе зоопланктона в некоторых участках $>0,5$ г/м водоему, а по средней биомассе зообентоса 3,85 г/м² - к $\alpha$-мезотрофному. 
Ключевые слова: зоопланктон, зообентос, озеро, Лама, Собачье, Кутарамакан.

\section{Введение}

До сих пор нет полных данных по важнейшим гидробиологическим характеристикам водоемов плато Путорана. Труднодоступность плато Путорана для исследователей - его расположение за Полярным кругом, незаселенность территории и отсутствие дорог - причины того, что этот регион остается одним из наименее изученных в гидробиологическом отношении. Среди Больших Норильских озер (Лама, Мелкое, Собачье, Глубокое, Кета) и других озер Путорана наиболее доступны Лама, Собачье и Кутарамакан (рис. 1), где существуют «базы» заповедников Таймыра и более или менее проработанная логистика.

Первые сведения о донной фауне о3. Лама получены в 1937 г. экспедицией Зональной промыслово-биологической станции Института полярного земледелия, животноводства и промыслового хозяйства в г. Игарке (Белых, 1940). В 1958-1959 гг. двумя экспедициями Сибирского отделения

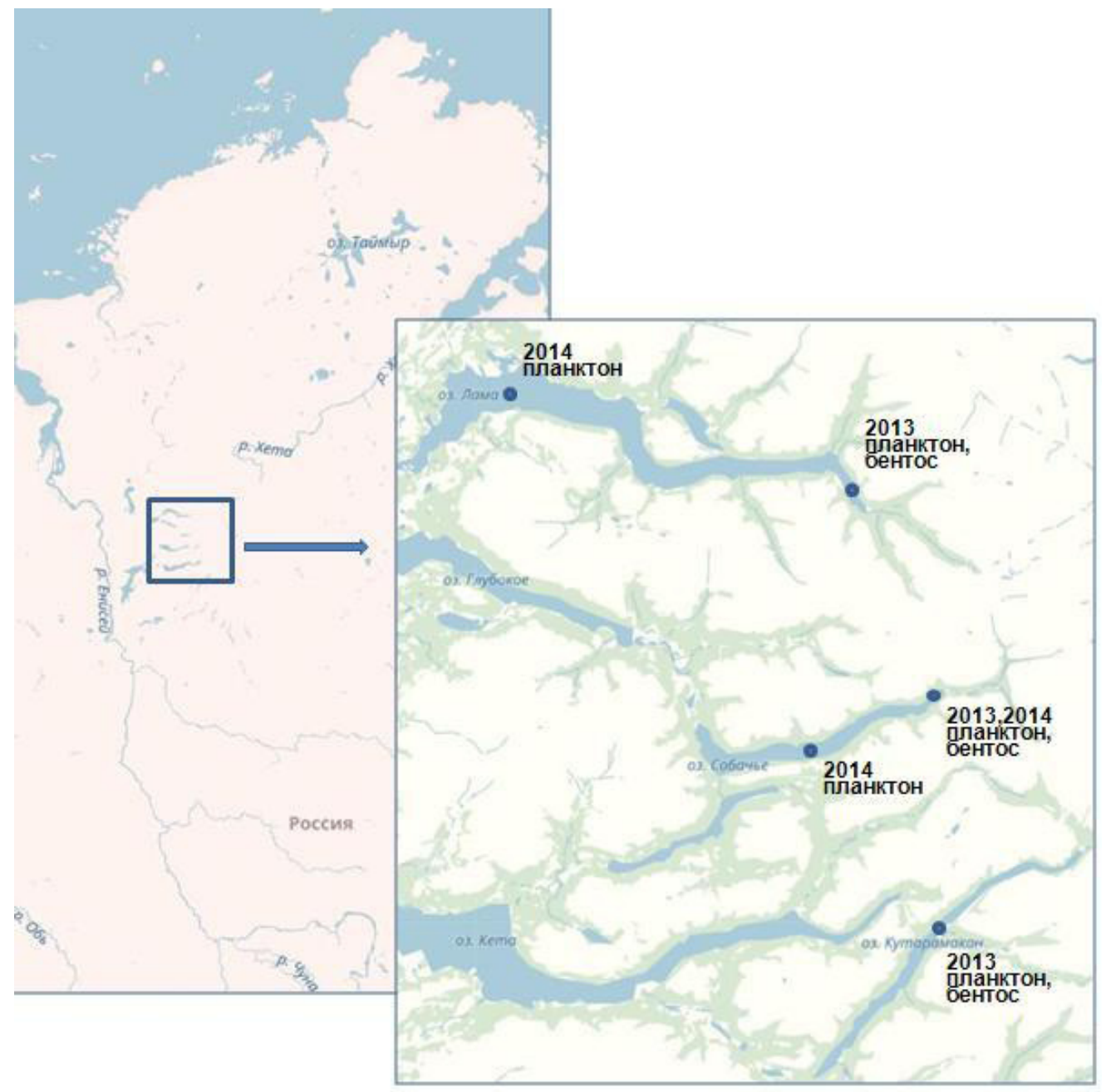

Рис. 1. Карта-схема исследуемых озер. Крупными точками обозначены районы отбора проб, занимающие несколько километров 
ГосНИОРХа (ныне НИИЭРВ) были собраны материалы по зоопланктону и зообентосу Норильских озер (в том числе Лама и Собачье) для оценки кормовых ресурсов рыб. В результате появились основательные работы: по зоопланктону озер - Л.Н. Гордеевой (1964), а по зообентосу - Н.В. Вершинина (1960а,б; 1963), Н.В. Вершинина и Л.В. Сычевой (1964). Выдающимися гидробиологическими исследованиями на Крайнем Севере как по трудности выполнения, так и по значению собранного материала и результатам остаются работы В.Н. Грезе $(1947 a, б)$ на оз. Таймыр. И.И. Грезе (1953) описала систематику и биологию личинок хирономид, собранных Л.Н. Лобовиковым и В.Н. Грезе в составе Таймырской экспедиции Сибирского отделения ВНИОРХ в тяжелые военные годы (1943-1944). В наше время по имаго установлен состав фауны хирономид Заполярья Красноярского края (Шилова, Зеленцов, 2000). В статье П.М. Долгих, Е.А. Ваганова (1993) приведена средняя численность и биомасса зоопланктона в пелагиали оз. Лама летом 1990 г. Следующая публикация, содержащая сведения о зоопланктоне оз. Лама и других водоемов Норильской промышленной зоны по сборам 2002 г., появилась только в 2003 г. (Andreev et al., 2003). Последняя статья по зоопланктону водоемов плато Путорана, в том числе озер Лама и Кутарамакан, вышла по результатам летних исследований 2001-2004 гг. (Dubovskaya et al., 2010). Проведено сравнение видового состава этого зоопланктона с таковым Большеземельской тундры (Fefilova et al., 2013). Других публикаций в рецензируемых журналах по зоопланктону и зообентосу изучаемых озер в период 1991-2016 гг. нами не найдено.

Исследование зоопланктона и зообентоса этих озер в настоящее время актуально в связи с происходящими изменениями, потенциально меняющими их структуру и функционирование: потеплением климата в Заполярье (Фефилова и др., 2014), в том числе и на Таймыре (Орлов, 2015); продолжающимся интенсивным воздействием воздушных выбросов Норильского ГМК (Zubareva et al., 2003); выловом рыбы (Андриенко и др., 2003). Цель работы - изучение видового состава и количественных показателей зоопланктона и зообентоса трех крупных озер плато Путорана (Лама, Собачье и Кутарамакан), сравнение полученных данных с предыдущими, оценка трофического статуса озер.

\section{Материалы и методы}

Большие Норильские озера Лама (318 км²), Собачье (99 км²) бассейна р. Пясина

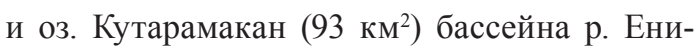
сей расположены в северо-западной части плато Путорана (рис. 1). Озера вытянуты в широтном направлении, горные, ледниковотектонического происхождения, проточные, со слабой минерализацией воды (13-42 мг/л). Содержание растворенного кислорода не опускается ниже 10 мг/л. Максимальная глубина достигает 100-250 м. В июле-августе температура воды в поверхностных слоях колеблется от 6,5 до $10,2{ }^{\circ} \mathrm{C}$, а в придонном слое - от 3,8 до $9,0{ }^{\circ} \mathrm{C}$. Температурный скачок выражен очень слабо и приурочен к глубинам 7-10 м (Вершинин, 1963; Богданов, 1985). На водосборах озер до отметок 250-400 м над ур. м. господствует лесная растительность и листвиничники, выше - кустарниковая и горная каменистая тундра. Толщина оттаивающего слоя вечной мерзлоты - от нескольких десятков сантиметров до 3-4 м. Климат резко континентальный, период открытой воды - 3,5-4 месяца. В озерах преобладают бурые илы, в зоне прибоя - каменистый грунт (Богданов, 1985). В июле 1993 г. в оз. Лама была низкая минерализация - сумма 
ионов не более 50 мг/л, вода мягкая (Са 8-15 мг/л, Mg 1-9 мг/л), pН между 7 и 8 показывал слабощелочную среду (Harwart et al., 1999). В сентябре 2013 г. амплитуда изменения температуры в столбе воды 0-25 м не превышала $1,1-1,9^{\circ} \mathrm{C}$, температура воды у поверхности на разных станциях трех исследуемых озер изменялась от 5,0 до $11,7^{\circ} \mathrm{C}$.

Зоопланктон отбирали в августесентябре 2013 г., а также в начале августа 2014 г. сетями Джеди (с ячеей 106 и 82 мкм). В центральной части озер (рис. 1) облавливали слои воды 0-5, 0-8 (0-10), 0-12, 0-15, 0-20, 0-25 м (озера Лама и Собачье), 0-5 м (оз. Кутарамакан). Дополнительно в прибрежье оз. Кутарамакан зоопланктон отбирали фильтрованием 100 л воды через сеть Апштейна. Все пробы фиксировали 4\%-м формалином. В 2013 г. обработано 18 проб, в 2014 г. - 4. Массу организмов находили по линейным размерам с помощью уравнений связи длины и массы тела (Методические рекомендации..., 1984). При установлении видовой принадлежности организмов использовали определители (Боруцкий и др., 1991; Определитель зоопланктона..., 2010; Определитель пресноводных..., 1994, 1995). Сходство видового состава зоопланктона оценивали индексом Жаккара (Песенко, 1982). Способ выделения доминирующих видов указан в примечании к табл. 1.

Зообентос изучали в восточных частях озер: в августе-сентябре 2013 г. - в оз. Лама (на 2 станциях), в оз. Собачье (на 2 станциях), в оз. Кутарамакан (на 4 станциях); в начале августа 2014 г. - в оз. Собачье (на 6 станциях), в середине августа - в 1,5 км выше устья р. Хоронен, впадающей с востока в оз. Собачье (рис. 1). Пробы отбирали в литорали с глубины 0,5-1,5 м круговым скребком Дулькейта (25 проб) и с глубины 3-11 м дночерпателем Петерсена (12 проб). Промывали через капроновый газ с размером ячеи 265 мкм. Фиксиро- вали 70\%-м этанолом, дальнейшую обработку проб проводили в лаборатории по общепринятым методикам (Методические рекомендации..., 1983). Видовой состав бентоса устанавливали в соответствии с определителями (Определитель пресноводных беспозвоночных..., 1994, 1995, 1997, 1999; Определитель насекомых..., 2006). Индекс видового разнообразия Шеннона-Уивера рассчитывали по численности (Песенко, 1982; Алимов, 2001). Средние величины и стандартные ошибки рассчитаны в Excel. Трофический статус озер определен по биомассе зоопланктона и зообентоса (Пидгайко и др., 1968; Китаев, 2007).

\section{Результаты}

\section{Зоопланктон}

В сентябре 2013 г. в оз. Кутарамакан обнаружено всего 5 видов сетного зоопланктона, доминировали копеподитные стадии Calanoida (Eudiaptomus gracilis) и коловратка Asplanchna priodonta helvetica (табл. 1). Численность и биомасса зоопланктона были очень низкие, особенно у берега (табл. 2). В оз. Лама эта коловратка была доминантом по биомассе, а мелкая коловратка Kellicottia longispina присутствовала в трех озерах (табл. 1), достигая максимума в слое 0-12 м 62,5 мг/ $\mathrm{M}^{3}$. Веслоногий рак Limnocalanus macrurus был субдоминантом на глубинах более 5 м в озерах Лама и Собачье. В оз. Собачье преобладали ветвистоусые раки рода Bosmina (до 25,4 мг/м ${ }^{3}$ ) и коловратка Trichocerca bicristata (табл. 1). Средняя биомасса зоопланктона во всех озеpax была не более 80 мг/м ${ }^{3}$ (табл. 2).

В августе 2014 г. в пелагиали центральной части оз. Лама (рис. 1) обнаружено 11 видов, из них 3 вида Calanoida, 1 - Cyclopoida и 7 видов Rotifera (табл. 1). По численности доминировал Limnocalanus macrurus - в основном половозрелые особи обоих полов и науплии (табл. 1). Основу биомас- 
Таблица 1. Видовой состав сетного зоопланктона исследуемых озер

\begin{tabular}{|c|c|c|c|c|c|c|}
\hline \multirow[b]{2}{*}{ Вид, группа } & \multicolumn{3}{|c|}{ Сентябрь 2013 г. } & \multicolumn{3}{|c|}{ Август 2014 г. } \\
\hline & $\begin{array}{l}\text { Лама } \\
\text { вост. } \\
\text { часть } \\
0-25 \text { м }\end{array}$ & $\begin{array}{c}\text { Собачье } \\
\text { вост. } \\
\text { часть } \\
0-25 \text { м }\end{array}$ & $\begin{array}{c}\text { Кутара- } \\
\text { макан } \\
\text { центр } \\
0-5 \text { м }\end{array}$ & $\begin{array}{c}\text { Лама } \\
\text { центр } \\
0-25 \text { м }\end{array}$ & $\begin{array}{c}\text { Собачье } \\
\text { вост. } \\
\text { часть } \\
\text { 0-30 м }\end{array}$ & $\begin{array}{c}\text { Собачье } \\
\text { центр } \\
\text { 0-30 м }\end{array}$ \\
\hline \multicolumn{7}{|l|}{$\begin{array}{l}\text { Веслоногие ракообразные - Copepoda: } \\
\text { Calanoida }\end{array}$} \\
\hline науплии Limnocalanus & & & & Дч & + & + \\
\hline Limnocalanus macrurus Sars & ++ & ++ & & Дб & ++ & Дб \\
\hline Eudiaptomus gracilis (Sars) & & & ++ & & & \\
\hline Arctodiaptomus (Rh.) acutilobatus (Sars) & & & & + & & \\
\hline Senecella calanoides Juday & & & & ++ & + & + \\
\hline Копеподитные стадии Calanoida & + & + & Дч & + & & \\
\hline $\begin{array}{l}\text { Cyclopoida } \\
\text { Cyclops abyssorum Sars }\end{array}$ & + & & & + & + & + \\
\hline Cyclops scutifer Sars & + & & ++ & & & \\
\hline Копеподитные стадии Cyclopoida & & & + & ++ & + & ++ \\
\hline Науплиальные стадии Copepoda & + & & & + & & + \\
\hline \multicolumn{7}{|l|}{ Ветвистоусые ракообразные - Cladocera: } \\
\hline Holopedium gibberum Zaddach & + & + & & & + & + \\
\hline Bosmina (Eubosmina) longispina Leydig & Дч & ++ & & & ++ & + \\
\hline Bosmina longirostris (O.F. Müller) & ++ & Дчб & & & & \\
\hline \multicolumn{7}{|l|}{ Коловратки - Rotifera: } \\
\hline Trichocerca bicristata (Gosse) & + & ++ & & & & \\
\hline Synchaeta grandis Zacharias & & & & & + & + \\
\hline Synchaeta lakowitziana Lucks & & & & + & + & Дч \\
\hline Synchaeta sp. & & & & + & & \\
\hline Polyarthra sp. & & & & + & + & \\
\hline Asplanchna priodonta helvetica Imhov & Дб & + & Дб & + & Дб & ++ \\
\hline Keratella cochlearis (Gosse) & & & & + & + & + \\
\hline Kellicottia longispina (Kellicott) & + & + & + & + & + & + \\
\hline Notholca squamula cristata Greze & & & & & & + \\
\hline Conochilus unicornis Rousselet & & & & + & Дч & + \\
\hline Всего видов & $10^{*}$ & $8 *$ & $5^{*}$ & 11 & 13 & 12 \\
\hline
\end{tabular}

Примечания: доминирующий вид (или группа) - первый в ранжированном ряду видов от большей к меньшей численности или биомассы, для каждой станции; Дчб - доминант по численности и биомассе; Дб - доминанат по биомассе; Дч - доминанат по численности; + - присутствует, ++ - субдоминант по биомассе - второй и третий виды в ранжированном ряду биомасс; * без видов, встречающихся в пробах единично.

сы составили Copepoda (табл. 2), а именно L. macrurus, копеподиты циклопов и калянида Senecella calanoides. Средняя для слоя 0-25 м биомасса сетного зоопланктона в ав- густе 2014 г. была 88 мг/м³ , что выше, чем в сентябре 2013 г. (табл. 2). В оз. Собачье (рис. 1) обнаружено 13 видов сетного зоопланктона: 2 вида Calanoida, 1 - Cyclopoida, 2 - Cladocera 
Таблица 2. Средняя численность (над чертой, экз $/ \mathrm{M}^{3}$ ) и биомасса (под чертой, мг/м ${ }^{3}$ ) групп сетного зоопланктона исследуемых озер в сентябре 2013 и августе 2014 гг.

\begin{tabular}{|c|c|c|c|c|c|}
\hline Год & Озеро & Copepoda & Cladocera & Rotifera & Всего \\
\hline \multirow{4}{*}{2013} & $\begin{array}{l}\text { Лама } \\
\text { восточная часть (0-25 м) }\end{array}$ & $\frac{325 \pm 50}{15 \pm 3}$ & $\frac{625 \pm 275}{5 \pm 2}$ & $\frac{490 \pm 225}{25 \pm 12}$ & $\frac{1440 \pm 530}{45 \pm 15}$ \\
\hline & $\begin{array}{l}\text { Собачье } \\
\text { восточная часть (0-25 м) }\end{array}$ & $\frac{465 \pm 330}{7 \pm 2}$ & $\frac{4260 \pm 720}{60 \pm 46}$ & $\frac{1870 \pm 530}{13 \pm 3}$ & $\frac{4790 \pm 1240}{80 \pm 50}$ \\
\hline & $\begin{array}{l}\text { Кутарамакан } \\
\text { центр (0-5 м) }\end{array}$ & $\frac{7 \pm 6}{10 \pm 9}$ & $\frac{2 \pm 1}{0}$ & $\frac{60 \pm 36}{6 \pm 5}$ & $\frac{70 \pm 30}{16 \pm 15}$ \\
\hline & $\begin{array}{l}\text { Кутарамакан } \\
\text { у берега }\end{array}$ & $\frac{80 \pm 50}{3,0 \pm 1,0}$ & $\begin{array}{l}\underline{0} \\
0\end{array}$ & $\frac{20 \pm 20}{1,5 \pm 1,5}$ & $\frac{100 \pm 70}{4,5 \pm 1,0}$ \\
\hline \multirow{3}{*}{2014} & $\begin{array}{l}\text { Лама } \\
\text { центр (0-25 м) }\end{array}$ & $\frac{1040}{87,4}$ & $\begin{array}{l}\underline{0} \\
0\end{array}$ & $\frac{234}{0,5}$ & $\frac{1274}{87,7}$ \\
\hline & $\begin{array}{l}\text { Собачье } \\
\text { центр (0-30 м) }\end{array}$ & $\frac{1709}{103,8}$ & $\frac{286}{9,7}$ & $\frac{8019}{48,0}$ & $\frac{10014}{161,6}$ \\
\hline & $\begin{array}{l}\text { Собачье } \\
\text { восточная часть (0-30 м) }\end{array}$ & $\frac{420}{44}$ & $\frac{2809}{33}$ & $\frac{31496}{432}$ & $\frac{34725}{509}$ \\
\hline
\end{tabular}

и 8 - Rotifera (табл. 1). Индекс сходства видового состава Жаккара между озерами Лама и Собачье высок $(0,73)$, что ожидаемо для озер одной водной системы (Норило-Пясинской). В оз. Собачье, как и в оз. Лама, обнаружена Senecella calanoides, из редких видов можно отметить коловратку Notholca squamula cristata, описанную В.Н. Грезе (1955). Доминируют по численности коловратки рода Synchaeta (с преобладанием S. lakowitziana) и Conochilus unicornis; а по биомассе - коловратка A. priodonta helvetica и в центральной части озера - Limnocalanus macrurus (табл. 1). Биомасса зоопланктона 509 мг/ м $^{3}$ самая высокая среди трех озер (табл. 2).

В августе-сентябре 2013-2014 гг. основу зоопланктона трех озер составляли веслоногие раки каляниды (E. gracilis в Кутарамакане, L. macrurus в Ламе и Собачьем), ветвистоусые рода Bosmina и вид Holopedium gibberum (в Ламе и Собачьем), коловратки A. priodonta (в трех озерах) и T. bicristata или виды рода Syncheta и Conochilus unicornis (в
Собачьем) (табл. 1). По соотношению вкладов отдельных групп в общую биомассу зоопланктона в сентябре 2013 г. оз. Лама являлось коловраточно-копеподным, оз. Собачье кладоцерно-коловраточным, а оз. Кутарамакан - копеподно-коловраточным, в августе 2014 г. зоопланктон оз. Лама и оз. Собачье был копеподно-коловраточным, а в восточной части оз. Собачье - коловраточно-копеподным (табл. 2).

\section{Зообентос}

Обнаружено 64 вида из 13 групп макрозообентоса, в том числе крупные представители мейофауны - ракушковые раки, нематоды и водяные клещи. В 2014 г. за счет бентоса р. Хоронен список лимнофильной фауны был дополнен реофильными личинками хирономид Orthocladius gr. olivaceus и Diamesa arctica. Наибольшее разнообразие наблюдается в группе хирономид - 42 таксона рангом ниже рода, и в группе водяных клещей -5 видов. Другие донные беспозво- 
ночные представлены беднее: в группах прочих двукрылых и олигохет - по 3 таксона, в группах амфипод и моллюсков - по 2, а остракоды, ногохвостки, пиявки, нематоды, жуки, ручейники, веснянки встречены единично (табл. 3).

Оз. Лама. В зообентосе обнаружено 7 групп организмов - бокоплавы, олигохе-

Таблица 3. Видовой состав зообентоса озер плато Путорана и р. Хоронен, 2013-2014 гг.

\begin{tabular}{|c|c|c|c|c|}
\hline \multirow{2}{*}{ Вид, группа } & \multicolumn{3}{|c|}{ Озера } & \multirow{2}{*}{$\begin{array}{c}\text { Река } \\
\text { Хоронен }\end{array}$} \\
\hline & Лама & Собачье & Кутарамакан & \\
\hline 1 & 2 & 3 & 4 & 5 \\
\hline \multicolumn{5}{|l|}{ кл. Nematoda - круглые черви } \\
\hline Nematoda indet. & + & + & + & \\
\hline \multicolumn{5}{|l|}{ кл. Oligochaeta - малощетинковые черви } \\
\hline Oligochaeta indet. & + & + & + & \\
\hline Tubifex tubifex (O.F. Müller, 1773) & & + & & \\
\hline Enchytraeidae indet. & & + & & \\
\hline \multicolumn{5}{|l|}{ кл. Hirudinea - пиявки } \\
\hline Hirudinea indet. & & + & & \\
\hline \multicolumn{5}{|l|}{ тип Mollusca - моллюски } \\
\hline Gastropoda indet. & & & + & \\
\hline Bivalvia indet. & + & + & + & \\
\hline \multicolumn{5}{|c|}{ кл. Arachnida, фаланга Hydrachnidia - водяные клещи } \\
\hline Acalyptonotus violaceus Walter, 1911 & & + & & \\
\hline Hygrobates $(H$.$) foreli (Lebert, 1874)$ & + & & & \\
\hline Lebertia (M.) densa Koenike, 1902 & & + & & \\
\hline Lebertia (P.) porosa Thor, 1900 & & + & + & \\
\hline Oxus (G.) setosus (Koenike, 1898) & & + & & \\
\hline \multicolumn{5}{|c|}{ кл. Crustacea, п/кл. Malacostraca - высшие раки, отр. Amphipoda - бокоплавы } \\
\hline Pallasea sp. & + & + & & \\
\hline Monoporeia affinis (Lindström, 1855) & + & + & & \\
\hline \multicolumn{5}{|c|}{ кл. Crustacea, п/кл. Ostracoda - ракушковые раки } \\
\hline Ostracoda indet. & & + & & \\
\hline \multicolumn{5}{|l|}{ кл. Insecta } \\
\hline Collembola indet. - ногохвостки & & + & & \\
\hline Coleoptera indet. - жуки & & + & + & \\
\hline Plecoptera indet. - веснянки & & + & & \\
\hline Trichoptera indet. - ручейники & + & + & & \\
\hline \multicolumn{5}{|l|}{ отряд Diptera - двукрылые } \\
\hline Sciaridae indet. & & + & & \\
\hline Tipulidae indet. & & + & + & \\
\hline Diptera indet. & & & + & \\
\hline \multicolumn{5}{|l|}{ сем. Chironomidae - хирономиды } \\
\hline Tanypodinae indet. & + & + & + & \\
\hline
\end{tabular}


Окончание табл. 3

\begin{tabular}{|c|c|c|c|c|}
\hline 1 & 2 & 3 & 4 & 5 \\
\hline Procladius gr. ferrugineus & & + & + & \\
\hline Procladius gr. choreus & + & & & \\
\hline Thienemannimyia sp. & + & + & + & \\
\hline Monodiamesa gr. bathyphila & + & + & & \\
\hline Diamesa arctica (Boheman,1865) & & & & + \\
\hline Pagastia lanceolata (Tokunaga, 1936) & & + & & \\
\hline Protanypus caudatus Edwards, 1924 & + & + & + & \\
\hline Pseudodiamesa gr. nivosa & + & & & \\
\hline Sympotthastia aff. fulva & + & + & & \\
\hline Abiskomyia sp. & + & + & + & \\
\hline Cricotopus sp. & & + & & \\
\hline Cricotopus gr. tibialis & + & & & \\
\hline Cricotopus (s. str.) gr. tremulus & & & + & \\
\hline Corynoneura gr. celeripes & & + & & \\
\hline Eukiefferiella gr. claripennis & & & + & \\
\hline Heterotrissocladius gr. marcidus & + & + & & \\
\hline Hydrobaenus sp. & + & & + & \\
\hline Krenosmittia camptophleps (Edwards, 1929) & & + & & \\
\hline Orthocladius gr. saxicola & + & + & + & \\
\hline Orthocladius gr. olivaceus & & & & + \\
\hline Parakiefferiella sp. & + & + & & \\
\hline Paraphaenocladius impensus (Walker, 1856) & & + & & \\
\hline Psectrocladius gr. delatoris & + & + & + & \\
\hline Rheocricotopus sp. & & + & & \\
\hline Tvetenia gr. bavarica & & + & + & \\
\hline Tvetenia gr. discoloripes & + & + & & \\
\hline Micropsectra sp. 1 & & & + & \\
\hline Micropsectra sp. 2 & & + & & \\
\hline Micropsectra sp. 3 & + & + & + & \\
\hline Micropsectra sp. 4 & + & + & & \\
\hline Paratanytarsus sp. & + & + & + & \\
\hline Tanytarsus sp. 1 & + & + & + & \\
\hline Tanytarsus sp. 2 & & + & & \\
\hline Chironomus sp. & + & + & & \\
\hline Einfeldia $\mathrm{sp}$. & & + & & \\
\hline Glyptotendipes (s. str.) juv. & & + & & \\
\hline Lipiniella sp. & + & + & + & \\
\hline Paracladopelma gr. camptolabis & & + & & \\
\hline Polypedilum sp. & & + & + & \\
\hline Sergentia gr. coracina & + & + & + & \\
\hline Stictochironomus sp. & + & + & & \\
\hline Куколки Chironomidae & & + & + & \\
\hline
\end{tabular}



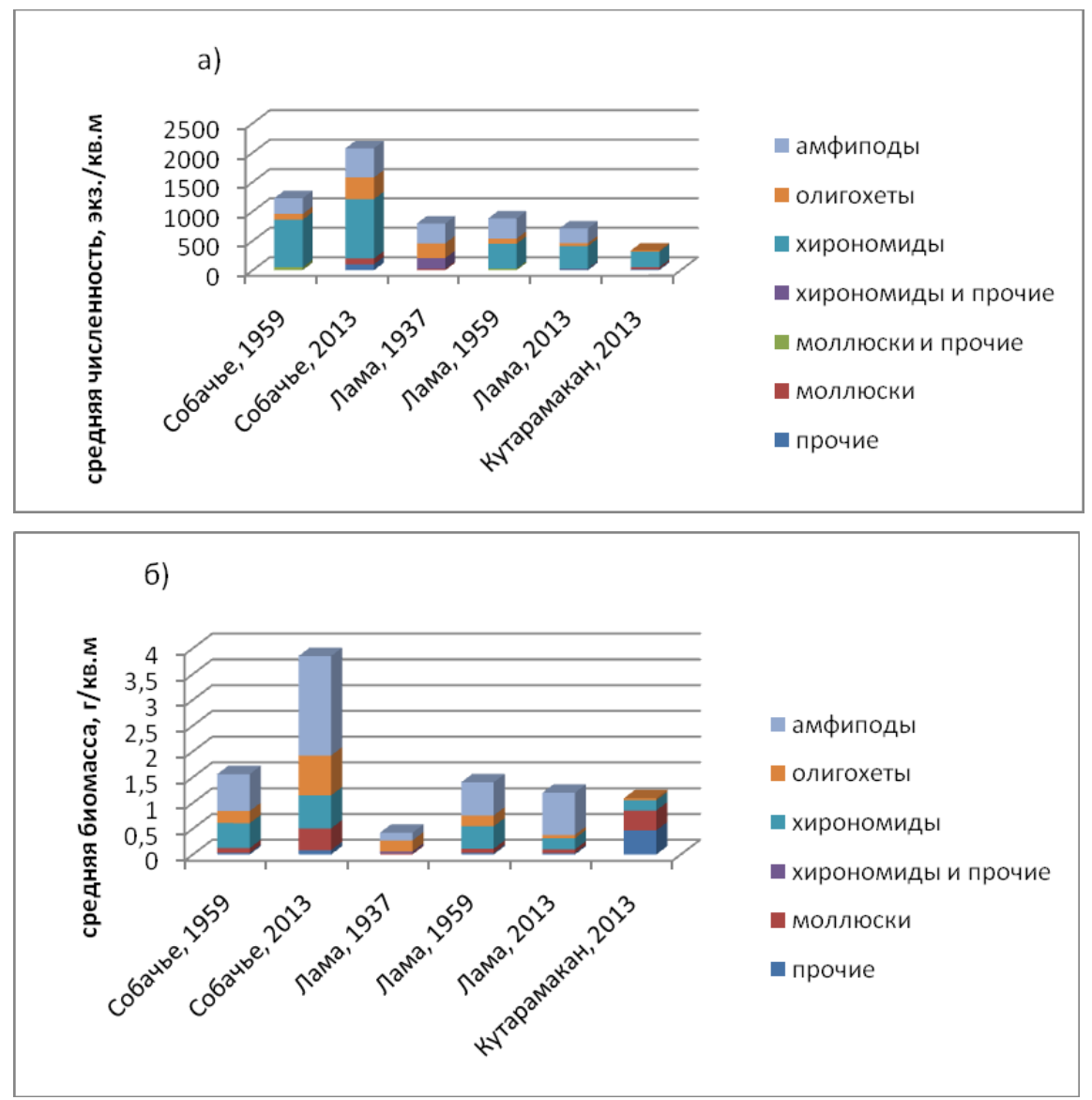

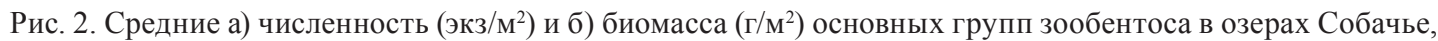
Лама и Кутарамакан в 1937 г. (средние рассчитаны по материалам Ф.И. Белых, 1940), 1959 г. (средние по Н.В. Вершинину, 1960б, 1963), 2013 г. (наши данные; в группе “прочие” - нематоды, пиявки, водяные клещи, остракоды, ногохвостки, жуки, веснянки, ручейники и двукрылые)

ты, хирономиды, нематоды, клещи, ручейники, моллюски. По численности (рис. $2 a$ ) на заиленных песках в прибрежье преобладали хирономиды (53,7 \%), субдоминанты - бокоплавы (35,1 \%). По биомассе доминировали бокоплавы - 68,3 \% от общей биомассы зообентоса, субдоминанты - хирономиды (рис. 2б). Индекс видового разнообразия Шеннона-

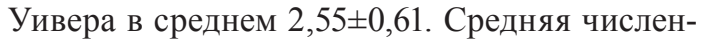
ность бентосных животных в начале сентября 2013 г. составила (708 \pm 144$)$ экз $/ \mathrm{M}^{2}$, биомасса $(1,20 \pm 0,32) \Gamma / \mathrm{M}^{2}$.

Оз. Кутарамакан. Донная фауна представлена 7 группами, это олигохеты, хи- рономиды, моллюски, клещи, двукрылые, нематоды и жуки. Бокоплавы в пробах отсутствовали (табл. 3). На каменисто-галечнопесчаных грунтах в прибрежной зоне развивались хирономиды, составляя $80 \%$ от общей численности (рис. 2a). По биомассе доминировали крупные личинки двукрылых насекомых (41,7 \% от общей биомассы), отнесенные в группу «прочие» (рис. 2б), субдоминанты - моллюски (35,4%). Наиболее часто встречались моллюски и олигохеты. Индекс Шеннона-Уивера в среднем равен 1,8土0,65. Количественные показатели зообентоса низ-

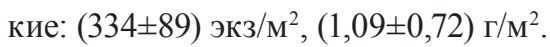


Оз. Собачье. Обнаружены 13 групп донных организмов - олигохеты, хирономиды, бокоплавы, моллюски, водяные клещи, веснянки, ручейники, ногохвостки, жуки, двукрылые, пиявки, остракоды и нематоды. Представители первых пяти групп встречались часто, остальные - редко и единично. По численности (рис. 2a) доминировали хирономиды (49,3\%), субдоминанты - бокоплавы (23,5 \%) и олигохеты (17,7 \%). Они составили основу донного биоценоза (в сумме 90,5 \% от общей численности бентоса). По биомассе (рис. 2б) преобладали бокоплавы (50,0 \%), субдоминанты - олигохеты, хирономиды и моллюски. Индекс видового разнообразия Шеннона-Уивера в среднем $2,37 \pm 0,63$. На мелководье озера до глубины 1-2 м отмечены каменистые грунты, а также заросли рдестов. Большую часть площади дна озера, начиная с глубины 2,5 м, занимают илистые и илистопесчаные грунты. Это наиболее богатые донные биотопы. Так, средняя численность зообентоса на илистых грунтах в 2013 г. до-

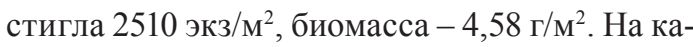
менистых грунтах эти показатели равнялись 800 экз $/ \mathrm{M}^{2}$ и 1,72 г $/ \mathrm{M}^{2}$. Основу биоценоза илов составили олигохеты, бокоплавы, хирономиды и моллюски. Оз. Собачье отличалось самыми высокими среди трех озер средними величинами численности и биомассы зообентоса $-(2073 \pm 370)$ экз $/ \mathrm{M}^{2}$ и $(3,85 \pm 0,69)$ г $/ \mathrm{M}^{2}$.

\section{Обсуждение}

\section{Зоопланктон}

В сравнении с предыдущими данными (Гордеева, 1964; Dubovskaya et al., 2010) в исследованный период численность и биомасса зоопланктона озер были ниже. Для оз. Лама ранее указывалось колебание средних величин общей летней биомассы 70-415 мг/м ${ }^{3}$ (Гордеева, 1964). По нашим данным, в столбе воды 0-25 м средняя биомасса составляла 45

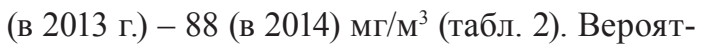
но, это связано с разницей во времени взятия проб нами (лето-осень) и другими исследователями (лето, Гордеева, 1964; Dubovskaya et al., 2010). К тому же 1959 г., когда Л.В. Гордеевой обнаружена высокая биомасса зоопланктона в оз. Лама (415 мг/м³), был теплым, а в относительно холодный 1990 г. биомасса была тоже низкой - 70 мг/м³ (Долгих, Ваганов, 1993). Основные доминирующие виды и группы, по нашим данным (табл. 1), совпадают с приводимыми в статье (Dubovskaya et al., 2010), а индекс сходства Жаккара списка из табл. 1 за август 2014 г. и из табл. 2, 4, 5 за июль 2003 г. (Dubovskaya et al., 2010) довольно высок - 0,5. В основном отличия касаются Cladocera, отсутствовавших в оз. Лама в июле 2003 г. (Dubovskaya et al., 2010), но являвшихся субдоминантами по биомассе в сентябре 2013 г. и присутствовавших в августе 2014 г. (табл. 1). Для оз. Кутарамакан, наоборот, из числа массовых видов в сентябре 2013 г. “выпала” кладоцера Daphnia galeata - доминант в июле 2003-2004 гг. (Dubovskaya et al., 2010). Наши данные, как и данные других авторов (Гордеева, 1964; Алексюк, Шульга, 1975; Шевелева, 1981; Dubovskaya et al., 2010), подтверждают, что ледниково-морской реликт Limnocalanus macrurus отсутствует в оз. Кутарамакан, как и в других озерах плато Путорана, не подвергавшихся четвертичной морской трансгрессии, в отличие от подвергавшихся этой трансгрессии Норильских озер, где он является характерным видом. Для оз. Кутарамакан характерен веслоногий рак Eudiaptomus gracilis. Сходство видового состава нашей табл. 1 и табл. 2, 4, 5 в статье (Dubovskaya et al., 2010) довольно высокое - 0,55. В оз. Кутарамакан биомасса зоопланктона в пелагиали $70 \mathrm{мг} / \mathrm{M}^{3}$ (табл. 2) значительно ниже, чем в 2003, 2004 гг. - $233 \mathrm{мг} / \mathrm{M}^{3}$ (Dubovskaya et al., 2010). Вероятно, это связано с различиями во 
времени и особенностях отбора проб, климатических характеристиках года.

Калянида Senecella calanoides указывается для исследованных водоемов, очевидно впервые, по крайней мере, нам неизвестны публикации о нахождении этого вида в Норильских озерах. Этот вид известен из опресненных участков морей Карского и Лаптевых, устьев впадающих в них некоторых рек и озер у Гыданского залива (Боруцкий и др., 1991). В северных американских озерах (Великих озерах - Верхнее, Гурон, Мичиган) этот вид известен давно (Carter, 1969; Balcer et al., 1984; Carter, Goudie, 1986). По-видимому, одной из причин его отсутствия в списках зоопланктона Норильских озер является слабая изученность водоемов Таймырского севера по сравнению с Великими американскими озерами. Другая причина - низкая встречаемость в пробах, взятых выше глубины 30 м, старших копеподитов, по которым возможно определение вида (по Боруцкий и др., 1991), - всего 1-4 экз. на пробу объемом 1470 л. В Великих американских озерах этот вид обитает в глубинных слоях, в осенне-зимний период уходит в более глубокие слои гиполимниона на дозревание и размножение (Carter, 1969). Однако возможен и двухлетний цикл развития сенеселлы в холодном гиполимнионе при низкой обеспеченности пищей (Carter et al., 1984), что вероятно в олиготрофных озерах, каковыми являются Лама и Собачье. Отличие или сходство обнаруженной нами пресноводной сенеселлы от Senecella siberica, описанной из прибрежных солоноватых вод моря Лаптевых (Vyshkvartzeva, 1994), планируется еще выяснить.

По классификации С.П. Китаева (2007) все исследованные озера по биомассе зоопланктона в сентябре 2013 г. относились к ультраолиготрофным (класс трофности “очень низкий”), как и в августе 2014 г. оз. Лама.
Озеро Собачье (по крайней мере его восточная часть) в августе 2014 г. характеризуется как олиготрофный водоем (класс трофности “низкий”), а не ультраолиготрофный (“очень низкий”).

\section{Зообентос}

Наиболее полные данные по зообентосу исследуемых озер ранее получены Н.В. Вершининым (1960б, 1963) на озерах Лама и Собачье. Он отмечает характерную для Заполярья бедность состава бентоса: число видов донных беспозвоночных колеблется от 46 (оз. Собачье) до 80 (оз. Лама). Из них $52 \%$ хирономиды, $13 \%$ - моллюски, $10 \%$ - олигохеты и $25 \%$ - прочие группы (Вершинин, 1963; Вершинин, Сычева, 1964). В наших сборах по числу видов также выделяются хирономиды, из которых в оз. Лама, Кутарамакан и Собачье найдены соответственно 23, 19 и 34 таксона (79, 73 и $65 \%$ от общего числа видов). Из хирономид в озерах Лама и Собачье (бассейн р. Пясина) часто встречались Monodiamesa gr. bathyphila, Protanypus caudatus, Heterotrissocladius gr. marcidus, Sergentia gr. coracina и танитарзины. В оз. Кутарамакан (бассейн рек Хантайки и Енисея) наиболее часто встречались Orthocladius gr. saxicola, Sergentia gr. coracina, Procladius gr. ferrugineus и танитарзины. Личинки танитарзин находят здесь для себя благоприятную кормовую базу в виде развивающихся в массе диатомей (Вершинин, 1963). В списке видового состава (табл. 3) большая часть таксонов определена до рода или группы видов, поскольку сбора имаго хирономид, необходимых для точного определения вида, не проводилось. А по имаго в фауне хирономид Заполярья в пределах Красноярского края А.И. Шилова, Н.И. Зеленцов (2000) выявили 206 видов из шести подсемейств: Podonominae - 1, Tanypodinae - 14, Diamesina- 
1, Prodiamesinae - 1, Orthocladiinae - 120, Chironominae - 69. Следовательно, при дальнейшем мониторинге озер можно ожидать расширения нашего списка хирономид.

В сборах по всем исследованным озерам большую часть видов составляют олигосапробные личинки стенооксибионтных и оксифильных хирономид подсемейств Orthocladinae (17 видов), Diamesinae (5 видов) и Prodiamesinae (Monodiamesa gr. bathyphila). И.И. Грезе (1953) также отметила преобладание личинок подсемейства Orthocladiinae (13 форм) над личинками подсемейства Tendipedinae $=$ Chironominae $(5$ форм $)$. К олигосапробам причисляют большинство представителей группы водяных клещей (Соколов, 1940). Все пять видов водяных клещей не были известны ранее для исследуемых озер. Два вида из этого списка, Lebertia (P.) porosa и Hygrobates (H.) foreli, были известны из Красноярского края (Соколов, 1940), остальные виды указываются для данного региона впервые.

По мере эвтрофирования водоема биоценозы упрощаются и индекс видового разнообразия Шеннона-Уивера снижается (Алимов, 2001). Вместе с тем в очень чистых водах происходит небольшое снижение величины индекса, поэтому кривая зависимости индекса от уровня трофности имеет куполообразный характер (Ляшенко, Протасов, 2003). Индекс видового разнообразия Шеннона-Уивера в среднем для всех проб по всем трем озерам составляет 2,21 $\pm 0,31$, что, по А.Ф. Алимову (2001), соответствует олиготрофным водоемам. Максимальная величина индекса 3,6 - на заиленных песках в озерах Лама и Собачье. Минимальные значения 0,6 получены при монодоминировании стенобионтных личинок хирономид Sergentia gr. coracina на илах в оз. Собачье. При эвтрофировании место монодоминантов обычно занимают поли- сапробы олигохеты Tubifex tubifex и личинки хирономид рода Chironomus. В нашем случае упрощение структуры бентоса происходит за счет других экстремальных факторов олиготрофии, паводковых явлений и круглогодичных низких температур придонной воды.

В.Н. Грезе (1947а, б) отмечал, что пониженная температура пресных вод Арктики обычно подавляет развитие водной флоры и фауны, причем наиболее грубым и непосредственным воздействием низких температур на жизнь водоема является зимнее промерзание в оз. Таймыр. Исследованные озера расположены южнее оз. Таймыр и по сравнению с ним более глубоководные, сохраняющие больший запас тепла, поэтому в них не замечено катастрофического влияния промерзания на фауну (Вершинин, 1963). Согласно Н.В. Вершинину и А.В. Сычевой (1964), до $88 \%$ качественного состава и до $68 \%$ биомассы бентоса сосредотачивается в литоральной зоне (от нижней границы прибойной зоны до 5 м). С глубиной бентос становится беднее, и в нижней профундали сохраняется только комплекс эвритермных форм с биомассой до 1,25 г/м². По нашим данным, бентос более или менее развит в литорали на глубинах с 3 до 11 м (рис. 3). Литораль глубже, и профундаль озер мы не исследовали. Концентрацию бентоса на указанных глубинах можно объяснить вертикальными миграциями донных беспозвоночных в связи с волновыми и сгонно-нагонными явлениями, характерными для этих озер.

При сравнении материалов прошлых лет с нашими данными (рис. 2) мы столкнулись с определенными трудностями: Ф.И. Белых (1940) поместил хирономид в группу с «прочими», а среди данных Н.В. Вершинина (1960б, 1963) отсутствуют отдельно сведения о численности моллюсков. Тем не менее 


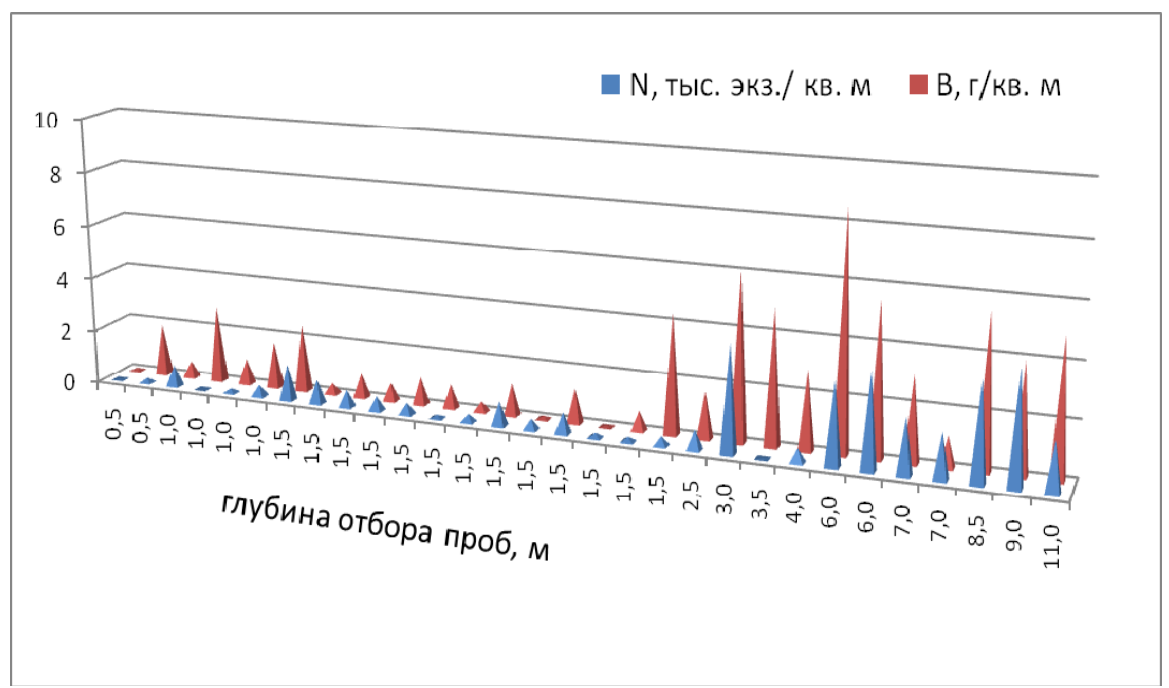

Рис. 3. Распределение общей численности (N) и биомассы (B) зообентоса озер Лама, Собачье и Кутарамакан по ранжированному ряду глубин (м), 2013 г.

наибольшая средняя биомасса зообентоса $(3,85$ г/м²), полученная в 2013 г. в оз. Собачье на илисто-песчаных грунтах, близка к приводимой Н.В. Вершининым (1963) биомассе псаммопелофильного биоценоза: в оз. Собачье 4,51 г/м² при численности 1417 экз/

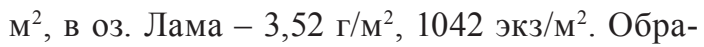
щает внимание отсутствие амфипод и доминирование по биомассе крупных личинок двукрылых (на рис. 26 в группе «прочие») в оз. Кутарамакан бассейна р. Енисей. В целом в оз. Лама и Собачье основными группами зообентоса являются амфиподы, хирономиды и олигохеты, а в оз. Кутарамакан - хирономиды, олигохеты и моллюски (рис. $2 a, \sigma)$. При оценке кормовой базы рыб (Пидгайко и др., 1968) по зообентосу литорали глубоководные озера Лама и Кутарамакан следует отнести к малокормным (биомасса до 3,0 г/м²), а оз. Собачье - к среднекормным

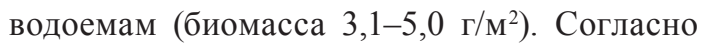
шкале трофности по биомассе зообентоса (Китаев, 2007) озера Лама и Кутарамакан являются ультраолиготрофными (“очень низкого” класса трофности), а оз. Собачье - $\alpha$-мезотрофным водоемом (“умеренного" класса трофности).

\section{Заключение}

Сравнение наших данных за августсентябрь 2013-2014 гг. с предыдущими годами показало, что видовой состав сетного пелагического зоопланктона озер Лама, Собачье и Кутарамакан существенно не изменился, в частности, среди доминантов в озерах Лама и Собачье, как и раньше, отмечен Limnocalanus macrurus, а в оз. Кутарамакан - Eudiaptomus graciloides. В 2014 г. впервые обнаружен новый вид для Норильских озер Лама и Собачье - Senecella calanoides (Calanoida). Биомасса зоопланктона озер в 2013-2014 гг. была ниже (Кутарамакан) или совпадала (Лама, Собачье) с нижними пределами в предыдущих исследованиях, но в 2014 г. в восточной части оз. Собачье оказалась более высокой $\left(>0,5 \Gamma / \mathrm{M}^{3}\right)$, классифицируя этот район как олиготрофный по сравнению с остальными ультраолиготрофными озерами. Оз. Собачье по доминированию кладоцер и коловраток также имеет более высокий уровень троф- 
ности, чем другие два озера. Аналогично по биомассе литорального бентоса оз. Собачье имело более высокий класс трофности - умеренный, соответствующий $\alpha$-мезотрофному водоему $\left(3,85 \Gamma / \mathrm{M}^{2}\right)$, а озера Лама и Кутарамакан были ультраолиготрофными. Впервые для региона указано 5 видов водяных клещей, а всего 6 видов беспозвоночных. Безусловно, дальнейшее планомерное исследование этих озер позволит уменьшить «белое» пятно в гидробиологии данного региона.

\section{Благодарности}

Авторы глубоко признательны Е.А. Макарченко и О.В. Орел, сотрудникам БПИ ДВО PAН, за консультацию и ценные замечания по систематике семейства хирономид. Работа частично поддержана Государственным заданием в рамках программы фундаментальных исследований РФ, тема 51.1.1, и грантом Президента Российской Федерации по государственной поддержке ведущих научных школ (НШ-9249.2016.5).

\section{Список литературы}

Алексюк А.П., Шульга Е.Л. (1975) Некоторые данные о зоопланктоне Путоранских озер. Путоранская озерная провинция: итоги ландшафтно-лимнологических исследований 1968 года. Пармузин Ю.П., Тюлина Л.Н. (ред.) Новосибирск, Наука, с. 194-199 [Aleksyuk A.P., Shul'ga E.L. (1975) Some data on the zooplankton of Putorana lakes. Putorana lake province: the results of landscape-limnological studies of 1968. Novosibirsk, Nauka, p. 194-199 (in Russian)]

Алимов А.Ф. (2001) Элементы теории функиионирования водных экосистем. СПб., Наука, 147 c. [Alimov A.F. (2001) Elements of aquatic ecosystem function theory. St. Petersburg, Nauka, 147 p. (in Russian)]

Андриенко А.И., Богданова Г.И., Михалев С.В. (2003) Состояние запасов рыб бассейна реки Пясины. Проблемы использования и охраны природных ресурсов Центральной Сибири. Bbin.4. Красноярск, Красноярский НИИ геологии и минерального сырья, с. 263-267 [Andrienko A.I., Bogdanova G.I., Mikhalev S.V. (2003) Status of fish stocks of Pyasina Basin. Problems of use and protection of natural resources in Central Siberia. Issue 4. Krasnoyarsk, Krasnoyarsk Research Institute of Geology and Mineral Resources, p. 263-267 (in Russian)]

Белых Ф.И. (1940) Озеро Лама и его рыбохозяйственное использование. Рыбохозяйственное значение Норильских озер (Мелкое и Лама). Суворов Е.К. (ред.) М.-Л., Издательство Главсевморпути, с. 73-100 [Belych F.I. (1940) Lake Lama and its fishery use. The Fishing importance of the Norilsk lakes (Melkoje and Lama). Suvorov E.K. (ed.) Moscow-Leningrad, Chief Administration of the Northern Sea route, p. 73-100 (in Russian)]

Богданов А.Л. (1985) История изучения, морфометрия и гидрология озер. География озер Таймыра. Л., Наука, с. 184-193 [Bogdanov A.L. (1985) Study history, morphometry and hydrology of lakes. Geography of Taimyr Lakes. Leningrad, Nauka, p. 184-193 (in Russian)]

Боруцкий Е.В., Степанова Л.А., Кос М.С. (1991) Onределитель Calanoida пресных вод СССР. СПб., Наука, 504 с. [Borutsky E.V., Stepanova L.A., Kos M.S. (1991) Key to identification of the Calanoida of freshwaters of USSR. St-Petersburg, Nauka, 504 p. (in Russian)]

Вершинин Н.В. (1960а) К вопросу о происхождении реликтовой фауны в Норильской группе озер. Доклады АН СССР, 135 (3): 753-755 [Vershinin N.V. (1960a) On the origin of the relict fauna in Norilsk Lakes Group. Reports of AS USSR [Doklady AN SSSR], 135(3): 753-755 (in Russian)] 
Вершинин Н.В. (1960б) Донная фауна Норильских озер. Рыбохозяйственное изучение Норильских озер: рукопись. Красноярск, СО ГосНИОРХ, с. 45-77 (Рукописный фонд НИИЭРВ. Т. 120). [Vershinin N.V. (1960b) Benthic fauna of Norilsk lakes. Fishery studying of Norilsk lakes: manuscript. Krasnoyarsk, Siberian Branch of State Institute of Lake and Fisheries, p. 45-77 (Manuscript fund of the Scientific Research Institute of Ecology of Fishery Reservoirs. V. 120) (in Russian)]

Вершинин Н.В. (1963) Норильские озера и их донная фауна. Гидробиологические работь на водоемах Советского Союза. М., Изд-во АН СССР, с. 63-72 [Vershinin N.V. (1963) Norilsk lakes and their benthic fauna. Hydrobiological works in the water bodies of the Soviet Union. Moscow, AS USSR, p. 63-72 (in Russian)]

Вершинин Н.В., Сычева А.В. (1964) Пищевые взаимоотношения рыб Норильской озерноречной системы. Рыбное хозяйство Восточной Сибири. Красноярск, с. 185-199 [Vershinin N.V., Sycheva A.V. (1964) Food relationship of fish of Norilsk lake-river system. Fish Industry of East Siberia. Krasnoyarsk, p. 185-199 (in Russian)]

Гордеева Л.В. (1964) Зоопланктон Норильских озер. Вопросы гидробиологии водоемов Карелии. Петрозаводск, Карельское книжное изд-во, с. 104-116 [Gordeeva L.V. (1964) Zooplankton of Norilsk lakes. Hydrobiological Issues of Karelia water bodies. Petrozavodsk, Karelskoe knijnoe izdatelstvo, p. 104-116 (in Russian)]

Грезе В.Н. (1947a) Анабиоз зообентоса Таймырского озера и его продуктивность. Зоологический журнал, 26 (1): 3-8 [Greze V.N. (1947a) The anabiosis of the zoobenthos of the Taimyr Lake and its productivity. Zoological Journal [Zoologicheskiy Zhurnal], 26 (1): 3-8 (in Russian)]

Грезе В.Н. (1947б) Таймырское озеро. Известия Всесоюзного гидрологического общества, 79 (3): 288-302 [Greze V.N. (1947b) Taimyr Lake. Bulletin of the Hydrologycal Society of the USSR [Izvestiya Vsesoyuznogo gidrologicheskogo obshchestva], 79 (3): 288-302 (in Russian)]

Грезе В.Н. (1955) К фауне коловраток Сибири. Заметки по фауне и флоре Сибири (18). Томск, Издание Томского государственного университета, с. 53-62 [Greze V.N. (1955) On the fauna of Siberia rotifers. Notes on fauna and flora of Siberia (18). Tomsk, Tomsk State University, p. 53-62 (in Russian)]

Грезе И.И. (1953) Личинки тендипедид Таймырского озера. Труды Иркутского государственного универсистета (Серия биологическая), 7(1-2): 77-82 [Greze I.I. (1953) Tendipedidae larvae of Taimyr Lake. Transactions of Irkutsk State University [Trudy Irkutskogo gosudarstvennogo universisteta (Seriya biologicheskaya)], 7(1-2): 77-82 (in Russian)]

Долгих П.М., Ваганов Е.А. (1993) К методике прогноза гидробиологических характеристик по дендрохронологическим данным в экосистемах крайнего Севера. Экология, 3: 73-75 [Dolgih P.M., Vaganov E.A. (1993) On the methods of prediction of hydrobiological characteristics on dendrochronological data in the ecosystems of the Far North. Ecology [Ekologia], 3: 73-75 (in Russian)]

Китаев С.П. (2007) Основы лимнологии для гидробиологов и ихтиологов. Петрозаводск, Карельский научный центр РАН, 394 с. [Kitaev S.P. (2007) Basic general limnology for hydrobiologists and ichthyologists. Petrozavodsk, Karel Scientific Centre of RAS, 394 p. (in Russian)]

Ляшенко А.В., Протасов А.А. (2003) Применение индексов разнообразия макрозообентоса как показателя состояния водных экосистем. Гидробиологический журнал, 39 (2): 17-27 
[Liashenko A.V., Protasov A.A. (2003) Application of macrozoobenthos diversity index as an indicator of the state of aquatic ecosystems. Hydrobiologycal Journal [Gidrobiologicheskij zhurnal], 39 (2): 1727 (in Russian)]

Методические рекомендации по сбору и обработке материалов при гидробиологических исследованиях на пресноводных водоемах. Зоопланктон и его продукиия (1984) Л., ГосНИOPX, 34 c. [Methodical Recommendations on Material Collection and Processing in Hydrobiological Studies in Freshwater Water Bodies: Zooplankton and Its Production (1984) Leningrad, State Institute of Lake and Fisheries, 34 p. (in Russian)]

Методические рекомендачии по сбору и обработке материалов при гидробиологических исследованиях на пресноводных водоемах. Зообентос и его продукиия (1983) Л., ГосНИОРХ, 52 c. [Methodical Recommendations on Material Collection and Processing in Hydrobiological Studies in Freshwater Water Bodies: Zoobenthos and Its Production (1983) Leningrad, State Institute of Lake and Fisheries, 52 p. (in Russian)]

Определитель зоопланктона и зообентоса пресных вод Европейской России. Т. 1. Зоопланктон (2010) Алексеев В.Р., Цалолихин С.Я. (ред.) М., Товарищество научных изданий КМК, 495 c. [Guide to freshwater zooplankton and zoobenthos of European Russia vol.1. Zooplankton. (2010) Alekseev V.R., Tsalolikhin S.Ya. (Eds.) Moscow-St. Petersburg, KMK Publishers, 495 p. (in Russian)]

Определитель пресноводных беспозвоночных России и сопредельных территорий (1994) T. 1. Цалолихин С.Я. (ред.) СПб., Наука, 395 с. [Key to freshwater invertebrates of Russia and adjacent lands (1994) Vol. 1. Tsalolikhin S.Ya. (ed.) St. Petersburg, Nauka, 395 p. (in Russian)]

Определитель пресноводных беспозвоночных России и сопредельных территорий (1995) Т. 2. Цалолихин С.Я. (ред.) СПб., Наука, 628 с. [Key to freshwater invertebrates of Russia and adjacent lands (1995) Vol. 2. Tsalolikhin S.Ya. (ed.) St. Petersburg, Nauka, 628 p. (in Russian)]

Определитель пресноводных беспозвоночных России и сопредельных территорий (1997) T. 3. Цалолихин С.Я. (ред.) СПб., Наука, 440 с. [Key to freshwater invertebrates of Russia and adjacent lands (1997) Vol. 3. Tsalolikhin S.Ya. (ed.) St. Petersburg, Nauka, 440 p. (in Russian)]

Определитель пресноводных беспозвоночных России и сопредельных территорий (1999) Т. 4. Цалолихин С.Я. (ред.) СПб., Наука, 999 с. [Key to freshwater invertebrates of Russia and adjacent lands (1999) Vol. 4. Tsalolikhin S.Ya. (ed.) St. Petersburg, Nauka, 999 p. (in Russian)]

Определитель насекомых Дальнего Востока России. Т. б. Двукрылые и блохи, Ч. 4 (2006) Лелей А.С. (ред.) Владивосток, Дальнаука, 936 с. [Key to the insect of Russian Far East. Vol. 6. Diptera and Siphonaptera. Pt 4. (2006) Leley A.S. (ed.) Vladivostok, Dal'nauka, 936 p. (in Russian)]

Орлов М.В. (2015) Об изменении климата на восточном Таймыре. Научные труды государственного природного заповедника «Присурский», 30 (2): 106-111 [Orlov M.V. (2015) On climate change on the eastern Taimyr. Proceedings of National Nature Reserve «Prisursky», 30 (2): 106-111 (in Russian)]

Песенко Ю.А. (1982) Принципы и методы количественного анализа в фаунистических исследованиях. М., Наука, 286 с. [Pesenko U.A. (1982) Principles and methods of quantitative analysis in faunal studies. Moscow, Nauka, 286 p. (in Russian)]

Пидгайко М.Л., Александров Б.М., Иоффе Ц.И., Максимова Л.П., Петров В.В., Саватеева Е.Б., Салазкин А.А. (1968) Краткая биолого-продукционная характеристика водоемов Северо- 
Запада СССР. Улучшение и увеличение кормовой базы для рыб во внутренних водоемах. (Известия ГосНИОРХ. Т. 67). Л., с. 205-228 [Pidgajko M.L., Aleksandrov B.M., Ioffe Ts.I., Maksimova L.P., Petrov V.V., Savateeva E.B., Salazkin A.A. (1968) Brief biologo-productional characteristic of water bodies of the North-West of the USSR. Improvement and increase in food supply for fishes in inland waters. (Bulletin of the Institute of Fresh Water Fisheries. Vol. 67). Leningrad, p. 205-228 (in Russian)]

Соколов И.И. (1940) Hydracarina - водяные клещи. Ч. 1: Hydrachnellae. Фауна СССР. T. 5 , выл. 2. Паукообразные. М.- Л., Изд-во Академии наук СССР, 511 с. [Sokolov I.I. (1940) Hydracarina. Part 1: Hydrachnellae. Fauna of USSR. Vol. 5, no. 2. Arachnides. Moscow-Lenungrad, Academia of Science of USSR, 511 p. (in Russian)]

Фефилова Е.Б., Батурина М.А., Кононова О.Н., Лоскутова О.А., Хохлова Л.Г., Дубовская О.П. (2014) Многолетние изменения в сообществах гидробионтов в Харбейских озерах. Журнал Сибирского федерального университета. Биология, 7 (3): 240-266 [Fefilova E.B., Baturina M.A., Kononova O.N., Loskutova O.A., Khokhlova L.G., Dubovskaya O.P. (2014) Long-term changes of aquatic communities in the Kharbeyskie lakes. Journal of Siberian Federal University. Biology [Zhurnal Sibirskogo federalnogo universiteta. Biologiya], 7 (3): 240-266 (in Russian)]

Шевелева Н.Г. (1981) Зоопланктон. Озера северо-запада Сибирской платформыл. Новосибирск, Наука, с. 123-135 [Sheveleva N.G. (1981) Zooplankton. Lakes of the North-West of the Siberian Platform. Novosibirsk, Nauka, p. 123-135 (in Russian)]

Шилова А.И., Зеленцов Н.И. (2000) Фауна хирономид (Diptera,Chironomidae) Заполярья в пределах Красноярского края. Биология внутренних вод, (2): 49-57 [Shilova A.I., Zelentsov N.I. (2000) Chironomids fauna (Diptera, Chironomidae) of the polar region within the Krasnoyarsk district. Inland Water Biology [Biologiya Vnutrennih Vod], (2): 49-57 (in Russian)]

Andreev V.P., Zhakovshchikova T.K., Ryabova V.N., Sorokoletova E.F., Sharygin A.A. (2003) Biological Analysis of Water Quality in the Noril'sko-Pyasinskaya System. Water Resources, 30 (4): 427-433

Balcer M.D., Korda N.L., Dodson S.L. (1984) Zooplankton of the Great lakes: A Guide to the Identification and Ecology of common Crustacean species. The University of Visconsin press, $173 \mathrm{p}$.

Carter J.C.H. (1969) Life cycles of Limnocalanus macrurus and Senecella calanoides, and seasonal abundance and vertical distributions of various planktonic copepods, in Parry Sound, Georgian Bay. Journal of the Fisheries Research Board of Canada, 26: 2543- 2560

Carter J.C.H., Dadswell M.J., Goudie M. (1984) Univoltine and semivoltine life histories in Senecella calansides (Gopepoda: Galanoida) and their relationship to body size. Canadian Journal of Fisheries and Aquatic Sciences, 41: 1167-1175

Carter J.C.H., Goudie K.A. (1986) Diel vertical migrations and horizontal distributions of Limnocalanus macrurus and Senecella calanoides (Copepoda, Calanoida) in lakes of southern Ontario in relation to planktivorous fish. Canadian Journal of Fisheries and Aquatic Sciences, 43: 2508-2514

Dubovskaya O.P., Kotov A.A., Korovchinsky N.M., Smirnov N.N., Sinev A.Yu. (2010) Zooplankton of Lakes in the Spurs of the Putorana Plateau and Adjacent Territories (North of Krasnoyarsk Krai). Contemporary Problems of Ecology, 3(4): 401-434 
Fefilova E., Dubovskaya O., Kononova O., Khokhlova L. (2013) A comparative survey of the freshwater copepods of two different regions of the Central Palaearctic: European and Siberian. Journal of Natural History, 47(5-12): 805-819

Harwart S., Hagedorn B., Melles M., Wand U. (1999) Lithological and biochemical properties in sediments of Lama Lake as indicators for the late Pleistocene and Holocene ecosystem development of the southern Taymyr Peninsula, Central Siberia. Boreas, 28: 167-180

Vyshkvartzeva N.V. (1994) Senecella siberica n. sp. and the position of the genus Senecella in Calanoida classification. Hydrobiologia, 292/293: 113-121

Zubareva O.N., Skripal'shchikova L.N., Greshilova N.V., Kharuk V.I. (2003) Zoning of landscapes exposed to technogenic emissions from the Norilsk mining and smelting works. Russian Journal of Ecology, 34 (6): 375-380 